\title{
Correction to: Science Education and the Pandemic, 1 Year On
}

\section{Emergence of New Conceptual Tools and Re-calibration of Existing Educational Approaches}

\section{Sibel Erduran ${ }^{1}$}

Accepted: 20 May 2021/ Published online: 18 July 2021

(c) The Author(s), under exclusive licence to Springer Nature B.V. 2021

\section{Correction to: Science \& Education (2021) 30:201-204 https://doi.org/10.1007/s11191-021-00201-6}

The article Science Education and the Pandemic, 1 Year On Emergence of New Conceptual Tools and Re-calibration of Existing Educational Approaches, written by Sibel Erduran, was originally published Online First with Open Access. After publication in volume 30, issue 2, page 201-204 the author decided to cancel the Open Access. Therefore, the copyright of the article has been changed to (C) The Author(s), under exclusive licence to Springer Nature B.V. 2021 with all rights reserved.

Publisher's Note Springer Nature remains neutral with regard to jurisdictional claims in published maps and institutional affiliations.

The online version of the original article can be found at https://doi.org/10.1007/s11191-021-00201-6

\section{Sibel Erduran}

Sibel.Erduran@education.ox.ac.uk

1 Department of Education, University of Oxford, 15 Norham Gardens, Oxford OX2 6PY, UK 